\title{
Estate Planning: Getting Started ${ }^{1}$
}

\author{
Josephine Turner²
}

Estate planning is a topic avoided by many individuals because it deals with attitudes and feelings about death, property ownership, business arrangements, marriage, and family relationships that family members may not be ready to discuss. It may also be avoided because family members disagree on how assets are to be handled.

Estate planning is no longer appropriate only to the "old" or "rich" but for everyone. The growing values of real estate and pension plans have increased the size of estates. In addition young couples often have minor children to consider in estate planning. In today's complex society all families regardless of ages and resources can benefit from including estate planning in their financial planning process. Estate planning includes a plan to transfer assets, a plan to manage assets if you become incapacitated, and a plan to care for minor children.

This is the first publication in a series on estate planning tools and techniques. Check with your local county extension agent for more information on the topics.

\section{What is Estate Planning?}

Estate planning is developing a definite plan for the administration and disposition of your property during life and at death. That is, it involves both handling your property while you are alive and dealing with what happens to that property after your death.

Estate planning involves three steps and the plan needs to be updated as your family situation changes. For example if you get married, divorced or widowed, your plan needs to be updated. If your health or financial status changes you will need to update your plan. The three basic steps are

(1) setting goals and objectives,

(2) the making of a will, and

(3) establishing a trust.

After experiencing the trauma of losing a loved one, quarreling over what the deceased would have wanted, and hunting for documents; most people would agree that it is worth spending some time and money to get their affairs in order to cut down on the confusion and uncertainty.

Most people would like to have a say in what happens to their property. An estate plan is a tool that provides some aspect of control. If you don't make a plan, state and federal laws will determine what happens to your property upon your death.

Your estate consists of everything you own including your home, other real estate, bank accounts, investments, retirement plans, and insurance policies. While a will is the cornerstone of an estate plan, other common transfer tools include joint ownership,

1. This document is FCS5239, one of a series of the Department of Family, Youth and Community Sciences, Florida Cooperative Extension Service, IFAS, University of Florida. Publication: December 2002 . Reviewed: Mary N. Harrison, professor of Consumer Education FYCS; Gary E. Pleiss, MA, FCS agent, Pinellas County; and Dena K. Wise, associate professor, Family Economics specialist, University of Tennessee. Please visit the EDIS Web site at http://edis.ifas.ufl.edu

2. Josephine Turner, CFP, Ph.D., professor of Family and Consumer Economics, Department of Family, Youth and Community Sciences, Cooperative Extension Service, IFAS, University of Florida, Gainesville, 32611. 
gifting, beneficiary transfers, and living trusts. You may choose several of these tools to manage your estate.

\section{Getting started}

If you live in Florida only part of the year, are you a Floridian? Do you have multi-state citizenship? To avoid more than one state claiming jurisdiction over some part of your estate, clearly establish residence in one state. You can show intent to be a Florida resident by such acts as registering to vote in Florida, opening bank accounts in Florida, obtaining a Florida driver's license, putting a Florida tag on your car, writing a Florida will, and filing your declaration of domicile at your county courthouse.

Accept the fact that you are going to die someday. Ask yourself some questions about what will happen if you do nothing. For instance if you should die before tomorrow:

- What would happen to the property you own?

- Who would take care of your dependents (minor children or aging relatives)?

- How would your spouse and children be provided for?

- What would happen to the family business?

- Would the estate settlement be conducted by someone with your family's interest and needs in mind?

- Would estate taxes, probate fees (often as high as 4 to $10 \%$ ), and other administrative and legal costs be held to a minimum?

\section{Six Steps}

Below are six steps that can help you as you get started in planning your estate.

Step 1: Communicate. Family members, all to often, are hesitant to discuss estate planning. For this reason, lack of communication is probably the greatest hurdle to overcome. Parents may wish to delay any discussion because of the unpleasant overtones of growing old and dying. Adult children may refrain from discussions about estate planning because they don't want to appear greedy or as if they are trying to take over.

Opportunities for mentioning the topic of estate planning may arise from publications, seminars, visit with bankers, attorneys, accountants, insurance representatives, and certified financial planners. A discussion of estate matters may come up in an incidental fashion and serve to initiate a discussion. The death of a friend, neighbor or relative may lead a family to realize that estate planning is not a subject to be overlooked.

Once a discussion is initiated, some families find it is easier to discuss their situation, concerns, and objectives. Difficult decisions may need to be made and they may be decisions upon which not all family members agree. The alternative of doing nothing allows state laws to decide how the estate is distributed.

Step 2: Collect information. Having necessary information and documents in hand for the first visit with your attorney and estate planning professionals can save time and money.

Below is a condensed checklist of information your estate planning professional will require. Actual documents may also be needed such as wills, deeds, major debt instruments, past gift tax returns, income tax returns and financial statements for the past five years, trust instruments, information about the income tax basis of property, and any other document that will clarify how property is titled or who would be responsible for any debt.

- Personal information: family members' names, birth dates, addresses, telephone numbers, occupations, social security numbers.

- Life insurance: company name and address, policy number, face value and any supplemental values, cash value and any outstanding policy loan, exact name of owner, name of insured and name of beneficiary.

- Checking and savings accounts: Name and location of institution, exact names on accounts, account numbers, amounts, how titled on signature card.

- Personal property: motor vehicles, home furnishing, jewelry, art, personal items, antiques, machinery, livestock, and crop inventory. Provide a description that includes cost, value, ownership, how titled.

- Real estate: type of property and size, location and description, year acquired, cost, how titled, market value. 
- Stocks, bonds, and other securities: description, when purchased, number, exact name of owner, face value, costs.

- Trusts: type, location, trustee, who established, exact name of beneficiary, value of trust property.

- Notes, mortgages and other accounts receivable: description, year acquired, value, person who owes you, repayment plan.

- Retirement benefits: pensions, profit sharing, deferred compensation, individual retirement accounts, social security, qualified domestic relations orders, amount invested, accrued benefits, annual benefits, death benefits.

- Mortgages and other real estate debts: description, name of creditor, date due and amount remaining to be paid, whether debt is an individual or joint responsibility, whether insured.

- Liens against personal property: description, name of creditor, date due, remaining amount to be paid, whether debt is an individual or joint responsibility, whether insured.

- Other personal liabilities: unsecured notes, notes endorsed, real estate taxes, personal property taxes, state taxes, federal taxes, unsettled claims (name of creditor, date due, amount remaining to be paid, whether debt is an individual or joint responsibility, whether insured).

- Other financial information: income last year, current income, salary, qualified domestic relations orders, retirement income, annuities, rents, interest, bonuses, dividends, trust, capital gains.

- Taxable gifts: amounts, when made.

- Location of important documents: all wills, trust documents, deeds, insurance policies, stocks and bonds, financial statements, income tax returns for last five years, gift tax returns, contracts, partnerships and corporation agreements, profit sharing plans, marriage dissolution decrees, pre-and post-nuptial agreements, employment contracts, pension benefits.

Step 3: Clarify Objectives. Estate planning objectives vary from family to family because of family values, differences in family size, number and ages of children, assets and liabilities, and family income. Objectives may change with age, marital status, income, kind of property acquired and other circumstances. Clarify your objectives and determine what you want to accomplish through your plan.

Listed below are some common objectives. Check those that apply to your situation and add others. If there is conflict among objectives, rank them in order of importance.

- Provide security for surviving spouse.

- Relieve surviving spouse of estate.

- Management responsibilities.

- Provide security for both spouses after retirement.

- Retire at age

- Provide security for an incapacitated family member.

- Assure continuity of family business.

- Provide educational opportunities for children.

- Assist children to get started in a business.

- Minimize estate taxes.

- Name guardian, conservators, or trustees of minor children.

- Name a personal representative for the estate.

- Provide means for paying expenses of estate settlement taxes and other debts.

- Provide equitable treatment of family members.

- Transfer specific property to specific people.

- Make gifts to family members and others during lifetime.

- Reduce income taxes by disposing of income property during life.

- Transfer property during life by installment sale.

- Provide for charitable bequest to favorite charities or organizations.

- Minimize probate and settlement costs.

- Review current operation and ownership of business, farm or ranch.

Step 4: Choose Professional Advisers. Estate planning is technical and complex and most people do not have the time to learn all they need to know in order to plan an estate thoroughly. A team of professionals such as attorneys, certified public accountants, financial advisers, trust officers, and life insurance underwriters can be of assistance. When selecting financial advisors seek recommendations from friends, coworkers, or professionals who have done legal work for you. Another source of information is the Yellow Pages in the telephone 
book. The Florida Bar has a system for telling the public which attorneys have special skills in certain areas of the law. Attorneys who have passed a rigorous written exam, been reviewed by peers, and maintained a satisfactory professional ethics record can apply for certification in Wills, Trusts and Estates for a five-year period. This is the highest classification a Florida attorney can attain. Even though not all good attorneys are board certified you can be assured that a Bar-certified attorney has a good reputation and a proven level of expertise.

\section{Step 5: Choose Alternatives and Implement the}

Plan. There are several strategies for reaching your objectives. Ask your advisors to explain the alternatives from legal as well as tax angles. Explore the consequences of the various strategies from the beneficiary's perspective as well as your own. Even though gifting is a great strategy to use, if there is any likelihood that you will need the gifted property to provide income for your later years, this is not a strategy you want to use. Decide who is to receive what, when, and how. Once the plan has been developed, it is important to implement it. Otherwise, the time, energy, and money involved have been wasted.

Step 6: Review Plan and Modify as Needed. Once you have completed your plan, keep a copy in your safe deposit box and another one at home so you can review it as needed. Your plan should be reviewed at least every five years and more often if your family situation or objectives have changed. If your family has increased or decreased through birth, adoption, death, marriage or divorce, you may need to make changes. If a family member has become disabled and dependent you may need to make changes. And of course, if tax laws change you will want to review your plan for the impact of the new laws.

\section{Summary}

Estate planning is time-consuming and laden with complex decisions and emotions. No one forces you to plan your estate, but the six steps identified above will help you get started. Once your plan is complete, and in place you can spend more time enjoying life and less worrying about the future.

\section{Disclaimer}

This publication is not intended to be a substitute for legal advice. Rather, it is designed to create an awareness of the need for estate planning and to help families become better acquainted with some of the devices involved. Further changes in laws cannot be predicted, and statements in this publication are based solely upon the laws in force on the date of publication.

\section{Acknowledgment}

Many thanks to Mr. Richard M. White, Jr., Florida Bar Certified in Wills, Trusts \& Estates, Gainesville, Florida, who reviewed this publication for accuracy.

\section{Reference}

Berteau, John T. 1998. Estate Planning in Florida $2^{\text {nd }}$ Edition. Sarasota, Florida: Pineapple Press, Inc.

Garman, E. Thomas and Forgue, Raymond E.2003. Personal Finance $7^{\text {th }}$ Edition. New York: Houghton Mifflin Co.

Kapoor, Jack R., Dlabay, Les R., and Hughes, Robert J. 2001. Personal Finance $6^{\text {th }}$ Edition. New York: McGraw-Hill Higher Education.

http://www.montana.edu/wwwpb/pubs/mt9508.html

Chapter 732 and 733 State Statutes

http://www.leg.state.fl.us 